\title{
The Economic and Social Effects of Unemployment in Romania
}

\author{
Sorin BURLACU ${ }^{1}$ \\ Amelia DIACONU ${ }^{2}$ \\ Evelina Petronela BALU ${ }^{3}$ \\ Iulian GOLE ${ }^{4}$
}

\begin{abstract}
Unemployment is considered as a negative element of economic development that affects in varying proportions all countries, especially those underdeveloped and those in transitions to the market economy. This paper presents the "Economic and Social Effects of Unemployment in Romania", where we presented the unemployment in the contemporary world, its typology and its measurement, namely: the evolution of the number of unemployed, a rate of unemployment and its structure in Romania. Unemployment has become a problem, along with industrial development, since the second half of the 18th century, in times of recession, when industrial enterprises shrank their production and therefore released a large number of workers who became unemployed. In Romania, unemployment is partly due to the transformation of the structure of a national economy, according to the criterion of efficiency, in order to adapt to the competitive environment.
\end{abstract}

Keywords: comparative administrative systems, parliament. transfer of good practices, know-how

JEL classification: D78, D73, H83.

DOI: $10.24818 /$ RMCI.2021.1.21

\section{Introduction}

Unemployment is analyzed in specialized literature from various angles, forming opinions that are the subject of wide controversy (Rădulescu et al., 2018). Over time, different definitions have been given for unemployment, taking into account the degree of scientific knowledge and the possibilities of measuring it (Profiroiu et al., 2020). Although there is this diversity in defining the concept of unemployment, it is still possible to uncover common elements that are found to be more or less proportionate in all opinions (Bodislav et al., 2020).

1 Sorin Burlacu, Bucharest University of Economic Studies, E-mail: sburlacu@amp. ase.ro

2 Amelia Diaconu, Senior Lecturer, Artifex University, Romania, E-mail: diaconu. amelia@gmail.com

${ }^{3}$ Evelina Petronela Balu, Ph.D. Student, Bucharest University of Economic Studies, Email: evelina.balu@yahoo.com

4 Iulian Gole, Ph.D. Student, Bucharest University of Economic Studies, E-mail: iuliangole@yahoo.com 
Unemployment is considered as a negative element of economic development that affects in varying proportions all countries (Bran et al., 2018), especially those underdeveloped and those in transition to the market economy (Negescu Oancea, et al., 2020). There are various ways of estimating unemployment and implicitly different ways of quantifying it (Androniceanu et al., 2017). We recall that, if we address the terms of the labor market, unemployment can be defined as a surplus of labor supply to the level of labor demand, and the unemployed can be considered as working-able persons who are not working, forming relative overpopulation, being in essence a surplus of workforce compared to the number of employees (Jianu et al., 2019).

Unemployment is a negative state of the available active population who finds no jobs because of the deregulation of the relationship between economic development as a source of labor demand and the evolution of the population as a source of labor supply (Carra et al., 2016). Under the contemporary conditions, unemployment is considered as an imbalance in the national labor market, is an imbalance between the global demand and the global labor supply (Rădulescu et al., 2018).

This imbalance reflects a surplus of labor supply over the labor force, with varying levels and meanings of development across countries and periods (Bran et al., 2018). It has initially been temporary in order to be permanent, but does not exclude completely and definitively the existence of an optimal employment status (Sarbu et al., 2021).

\section{Evolution of Unemployed Number in Romania}

Unemployment is a phenomenon that can't be stopped but which, through the economic measures being taken, must be controlled. This phenomenon has been a contradictory development, and in some periods of the past years one can speak of growth. At the end of January 2017, the national unemployment rate was $4.92 \%$, higher by $0.25 \mathrm{pp}$ than in December 2016. The male unemployment rate (4.5\%) increased by $0.8 \mathrm{pp}$ in December 2017 compared to the previous month and the female unemployment rate (4.4\%) increased by $0.5 \mathrm{pp}$. Comparing the indicators of each year can note that unemployment as a whole is characterized by a decrease, both at the level of the country as well as at the county level. The labor market in Romania was characterized by a constant rate throughout the year 2017, with a slight increase in December, the average being of $4.5 \%$.

Table 1- Unemployment rate by age groups, sexes and averages, in the third quarter of 2020

\begin{tabular}{lcccc}
\hline \hline & Male & Female & Urban & Rural \\
\hline \hline 15-24 years & 18,8 & 19,9 & 24,5 & 16,7 \\
25-34 years & 6,9 & 5,9 & 5,8 & 7,6 \\
35-44 years & 3,9 & 3,3 & 3,1 & 4,5 \\
45-54 years & 3,6 & 4,1 & 3,1 & 4,7 \\
55 years and over & 2,6 & 2,7 & 3,6 & 1,9 \\
\hline \hline
\end{tabular}

Source: Romanian National Institute of Statistics (insse.ro)

22 Review of International Comparative Management

Volume 22, Issue 1, March 2021 
As can be seen from the data in Table 1, In the third quarter of 2020, the employment rate of the working age population (15-64 years) was $66.0 \%$, up from the previous quarter. In the third quarter of 2020 , the employment rate 1 of the population aged $20-64$ was $71.2 \%$, with 1.2 percentage points above the national target of $70 \%$ set in the context of the Europe 2020 Strategy. In the third quarter of the year 2020, the active population of Romania was 9027 thousand people, of which, 8555 thousand people were employed and 472 thousand people were unemployed (INS, 2021).

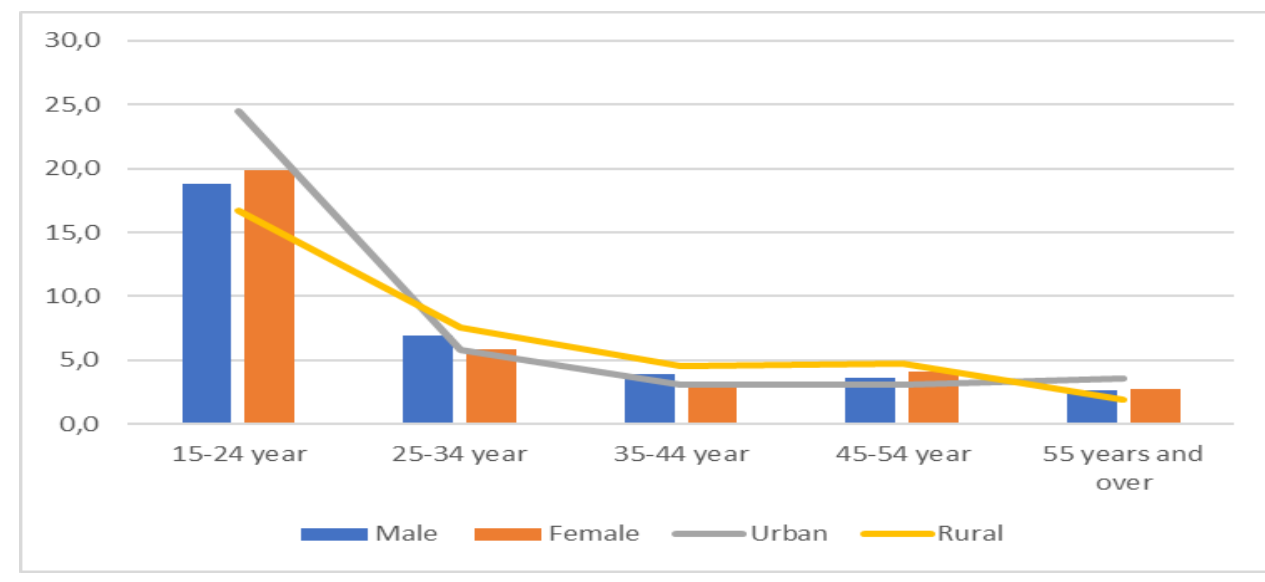

Figure 1- Unemployment rate by age groups, sexes and averages, in the third quarter of $\mathbf{2 0 2 0}$

Source: Made by authors based on INS data

Figure 1 shows that the employment rate of the working age population (15-64 years) was, in the third quarter of $2020,66.0 \%$, up from the previous quarter by 0.8 percentage points. The employment rate was higher for men (74.9\% compared to $56.9 \%$ for women) and for people in urban areas (67.4\% compared to $64.4 \%$ in rural areas). The employment rate of young people (15-24 years) was $24.7 \%$

\subsection{Evolution of the unemployment rate in Romania}

Unemployment is not only determined by the level of education, as there are areas where the unemployment of the highly qualified is high and at the same time the demand for unskilled workers is uncovered, with the need for a particular analysis of the unemployment structure. Exodus of rural youth is often perceived as a challenge for sustainable rural development, but this relocation may be the best option for young people.

Young people's perception of the rural area depends on geographical location, social environment, infrastructure, services, accessibility, the local labor market, and the role of family, friends and social networks. 
After 2005 there is a decrease in unemployment in the urban area, but since 2009 there has been an increase in unemployment as a result of the economic crisis that has affected Romania's economy as well. At present, in spite of salary increases and the assumption of new jobs in the labor market, the situation remains framed in negative parameters.

Table 2. Evolution of the employment rate of the population aged 15 and over, by age groups

\begin{tabular}{|c|c|c|c|c|c|}
\hline & Tr. III 19 & Tr. IV 19 & Tr. I 20 & Tr. II 20 & Tr. III 20 \\
\hline $15-24$ years & 25,6 & 24,4 & 23,9 & 24,4 & 24,7 \\
\hline $25-54$ years & 82,1 & 81,6 & 80,8 & 80,2 & 80,9 \\
\hline 55-64 years & 48,9 & 48,1 & 47,6 & 48,2 & 49,6 \\
\hline 65 years and over & 7,8 & 7,1 & 6,7 & 7,0 & 7,0 \\
\hline
\end{tabular}

Source: Romanian National Institute of Statistics (insse.ro)

As can be seen in Table 2 and Figure 2, respectively, the unemployment rate in the third quarter of 2020 was $5.2 \%$, down 0.2 percentage points from that recorded in the previous quarter. According to INS data, by sex, the gap between the two unemployment rates was 0.4 percentage points (5.4\% for men compared to $5.0 \%$ for women), and for residential areas, 1.2 percentage points (5.9\% in rural areas, compared to $4.7 \%$ in urban areas), and by age groups, the unemployment rate reached the highest level (19.2\%) among young people (15-24 years).

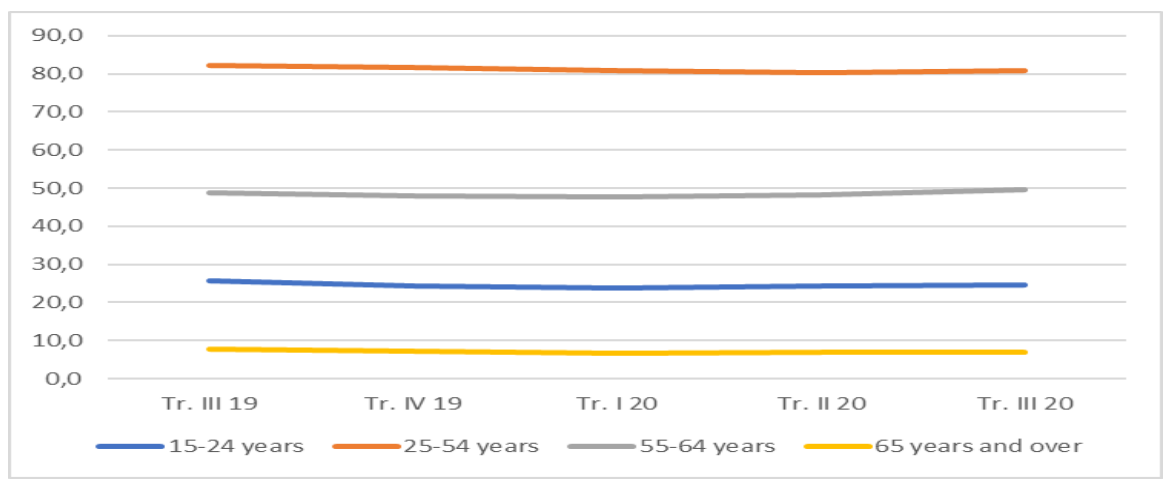

Figure 2. Evolution of the employment rate of the population aged 15 and over, by age groups

Source: Made by authors based on INS data

There are no visible results on unemployment, and the effects on income are mainly the result of the influence of low wages in the source regions of migration. These counterintuitive results can be explained by the motivation of partial interregional migration decisions as a result of the process of collectivization of Romanian agriculture. 
This has given development opportunities in the rural economy, while the potential of urban areas has been affected by high unemployment rates. As a result, a migration process from the urban to the rural area has occurred, involving interregional relocation as well.

The analysis of the annual differences between the directions of migration reveals the existence of a "attraction phenomenon" rather than a one of "rejection" of the rural area, a phenomenon justified by the rationality of the choice based on the income analysis. This fact emphasizes the importance in perspective of socioeconomic factors such as housing, health service infrastructure, human capital, factors to be analyzed in interregional migration research. Expanding economic models to include significant socio-economic conditions in relocation decisions is also a direction of future research, conditional upon the existence of recent and relevant data on internal migration in Romania.

\subsection{Unemployment structure}

The structure of registered unemployment tilts the balance to those in the adult age category, over 40 (about $42 \%$ of the total unemployed, average in the first quarter of 2017). The average percentage of unemployed aged under 25 registered in the Agency's records during January-March 2017 was about $20 \%$.

The number of young people in employment stimulation measures in the first three months of 2017 was 45,318 and the number of people aged over 45 was 78,310 . At the territorial level, the number of unemployed decreased in Bucharest and in most of the counties, with the largest decreases registered in the counties: Constanta (1883 persons), Dâmboviţa (1679 persons), Alba (with 1700 persons), Dolj with 1686 people), Harghita (1462 persons) and Mures (with 1327 persons).

The unemployment rate fell in most counties, with the highest decreases registered in the counties: Ialomita with $0,92 \mathrm{pp}$, Harghita and Mehedinti by 0,86 pp, Alba by $0,78 \mathrm{pp}$, Vaslui and Dâmboviţa by $0,72 \mathrm{pp}$ and Tulcea with $0.65 \mathrm{pp}$.

The counties with the highest share of unemployed unemployed in the total number of the unemployed are Teleorman $(81.76 \%)$, Dolj $(80.86 \%)$, Galati (78.37\%), Iasi $(79.08 \%)$, Vrancea $76.85 \%)$, Braila (78.25\%), Calarasi $(78.88 \%)$ and Buzau (78.6\%).

\section{Conclusion}

Employment policy is part of a country's social policy, alongside pensions and other social security rights, social assistance and family policies, employment relationships, occupational safety and health, health insurance, housing and housing policies, education policies, social policies of delinquent people and other social policies. The strategy and employment policies should start from the setting of some fundamental objectives: Economic growth through the creation of new productive units and thereby new jobs, especially in the key sectors of the economy; Growth of research-innovation and education jobs at a higher pace,

Review of International Comparative Management

Volume 22, Issue 1, March 2021 
while giving more attention to staff in these sectors (wages, material basis, documentation, relations with other countries, etc.); Stimulating the technological progress of enterprises by bringing them to the (near) level of competitiveness in other countries; Making more serious changes in working conditions and the work system so as to generate a sustainable motivation for tenderers to take up available jobs; Forming and supporting a new managerial class empowered for competitive businesses in the tough conditions of globalized economies; Measures designed to create and strengthen a middle class capable of competing with large enterprises in particular those in relation to foreign companies operating in Romania; A great source of new job creation is the rural economy, where there is numerous demand for services and unoccupied workforce availability. A future direction of research will be to consider the impact of measures on the labor market due to the COVID19 pandemic ((Radulescu et al., 2021).

\section{References}

1. Alpopi, C.; Burlacu, S.; Ioviţu, M.. (2018) Procesul de globalizare şi politicile ecologice. In: Competitivitatea şi Inovarea în Economia Cunoaşterii. Vol.2, 28-29 septembrie 2018, Chişinău, Republica Moldova: Departamentul Editorial-Poligrafic al ASEM, 2018, pp. 317-324. ISBN 978-9975-75-931-1.

2. Androniceanu, A., Burlacu, S., Drăgulănescu, I. V., \& Nicolae, E. E. (2017, May). New trends of businesses digitalization in Romania and the behaviour young consumers. In BASIQ International Conference: New Trends in Sustainable Business and Consumption, Graz (Vol. 31, pp. 27-35).

3. Bodislav, D. A., Buzoianu, O. A. C., Burlacu, S., \& Rădulescu, C. V. (2020). Analysis of companies in Romania from the perspective of risk perception and the management needs thereof. Economic Convergence in European Union, 341.

4. Bran, F.., Alpopi, C., \& Burlacu, S. (2018). Territorial Development-Disparities between the Developed and the least Developed Areas of Romania. LUMEN Proceedings, 6(1), 146-155.

5. Burlacu, S., Gavrilă, A., Popescu, I. M., Gombos, S. P., \& Vasilache, P. C. (2020). Theories and Models of Functional Zoning in Urban Space. Revista de Management Comparat International, 21(1), 44-53.

6. Carra, C., Burlacu, S., \& Faggianelli, D. (2016). VIOLENCE WITHIN ORGANIZATIONS IN THE HEALTH AND MEDICO-SOCIAL SECTORS, COMPARATIVE ANALYSIS FRANCE-ROMANIA. Administratie si Management Public, (27), 123.

7. Jianu, I., Dobre, I., Bodislav, D. A., Radulescu, C. V., \& Burlacu, S. (2019). THE IMPLICATIONS OF INSTITUTIONAL SPECIFICITIES ON THE INCOME INEQUALITIES DRIVERS IN EUROPEAN UNION. Economic Computation and Economic Cybernetics Studies and Research, 53(2), 59-76.

8. Negescu, M D; Burlacu, S; Mitriţă, M; Buzoianu, O C A. Managerial Analysis of Factoring at the International Level Challenges of the Contemporary Society. Proceedings; Cluj-Napoca Vol. 13, Iss. 1: 99-102. Cluj-Napoca: Babes Bolyai University. (2020)

26 Review of International Comparative Management

Volume 22, Issue 1, March 2021 
9. Profiroiu, C. M., Bodislav, D. A., Burlacu, S., \& Rădulescu, C. V. (2020). Challenges of Sustainable Urban Development in the Context of Population Growth. European Journal of Sustainable Development, 9(3), 51-51.

10. Radulescu, C.V.; Ladaru, G.-R.; Burlacu, S.; Constantin, F.; Ioanăş, C.; Petre, I.L. (2021) Impact of the COVID-19 Pandemic on the Romanian Labor Market. Sustainability 2021, 13, 271. https://doi.org/10.3390/su13010271

11. Rădulescu, C. V., Bodislav, D. A., \& Burlacu, S. (2018). DEMOGRAPHIC EXPLOSION AND IT GOVERNANCE IN PUBLIC INSTITUTIONS. Managerial Challenges of the Contemporary Society. Proceedings, 11(1), 18.

12. Rădulescu, C. V., Dobrea, R. C., \& Burlacu, S. (2018) THE BUSINESS MANAGEMENT OF DISTRESS SITUATIONS. THE 12th INTERNATIONAL MANAGEMENT CONFERENCE "Management Perspectives in the Digital Era" Novembre 1st-2nd, 2018, BUCHAREST, ROMANIA, 1, 741-747

13. Sarbu, R., Alpopi, C., Burlacu, S., \& Diaconu, S. (2021). Sustainable urban development in the context of globalization and the health crisis caused by the covid-19 pandemic. Les Ulis: EDP Sciences. doi:http://dx.doi.org/10.1051/ shsconf/20219201043 